\title{
THE ECONOMIC VALUE OF LANDSCAPE AESTHETICS IN ALBUFERA NATURAL PARK THROUGH THE ANALYTIC MULTICRITERIA VALUATION METHOD
}

\author{
VICENTE ESTRUCH-GUITART ${ }^{1}$ \& MARÍA VALLÉS-PLANELLS ${ }^{2}$ \\ ${ }^{1}$ School of Agricultural Engineering and Environment, Department of Economy and Social Sciences, Group of \\ International Economics and Development, Universitat Politècnica de València, Spain. \\ ${ }^{2}$ School of Agricultural Engineering and Environment, Department of Animal Science, Centre of Aquaculture and \\ Environment, Universitat Politècnica de València, Spain.
}

\begin{abstract}
The effective definition of public intervention goals and resource allocation for natural resource management requires decision makers to understand the monetary values of the full range of goods and services provided by landscapes, in other words, their Total Economic Value (TEV). Aesthetic enjoyment (AE) can be considered as part of such TEV of landscapes. For the estimation of the economic value of AE in Albufera Natural Park (Valencia, Spain), this paper applies the Analytic Multicriteria Valuation Method (AMUVAM). It is a combination of two established techniques: analytic hierarchy process (AHP) and discount cash flow (DCF). The economic value of non-market benefits under AMUVAM is obtained indirectly, by comparing the relative degrees of importance attached to the different components of TEV. In this way, not only does it estimate a monetary value of AE but also its importance relative to TEV. Results express that AE represents 7\% of the TEV in Albufera Natural Park and $24 \%$ of the EV in Albufera Natural Park (€176 million). Results reveal distinct patterns in the valuation of TEV and existence value (EV). In this way, together with the average, a range of values which show the different sensitivities of society is provided. The comparison of the TEV obtained for Albufera Natural Park with previous studies conducted on wetlands suggests its similarity in scale.

Keywords: analytical hierarchy process, economic value, landscape valuation, multicriteria decision making, wetland.
\end{abstract}

\section{INTRODUCTION}

Landscapes provide benefits to human society, which are important for economic (productive), sociocultural and ecological reasons [1]. However, the full value of the landscape is rarely taken into account in economic analysis [2]. This paper focuses on the valuation of landscape aesthetics, as a component of the Total Economic Value (TEV) of a landscape.

In the scientific literature, a distinction is made between valuation and evaluation or assessment of aesthetic quality [3, 4], measures that require different methods of assessment. While assessment of the aesthetic quality of a landscape is defined as the relative aesthetic excellence of a landscape area, compared with other areas, valuation refers to the worth of a given level of aesthetic quality, relative to other values, resources, human desires and needs [5].

With regard to the assessment of the aesthetic value of landscapes, also known as visual quality, there is a long tradition of work in this area, work that began in the field of forestry in the United States due to the need to incorporate assessments of aesthetic value into forest planning and management [6]. However, research on visual landscape quality evaluation has not achieved a commonly accepted "aesthetic theory" that explains why one landscape would be rated as better, or more socially desirable, than another. The reason for this is that the beauty of a landscape depends not only on its intrinsic characteristics, but also on its context and on the biological, cultural and personal characteristics of the observer [7-10]. In addition, visual landscape quality evaluation has usually involved ranking landscapes on ordinal [11-14] rather than on absolute scales, with the exception of the work developed by Fines 
[15]. Hence, such methods do not allow for comparisons of evaluations conducted in different geographical areas [16].

With regard to the economic valuation of aesthetic quality, a field that also began in the 1970s [17], the most frequently used methods are revealed preference and stated preference [18]. Revealed preference techniques are based on people's actual behaviour in real markets, in relation to the consumption of particular goods [19-22]. The focus of these methods is to estimate the economic value of landscapes at a certain moment, in order to provide information to policy makers to justify preservation or allocation of resources. The second category, stated preference methods, focuses on change involving both negative and positive [23, 24] impacts on landscape. Such methods assume that there is no related market for landscapes, but that a hypothetical market can be constructed. Unlike revealed preference, stated preference methods include non-use values and are addressed to changes in valuations of landscapes, rather than to the valuation of landscape "per se" [25].

Concerning the natural resources management point of view, not only is it important to know the absolute value of a certain service (e.g. AE) but also to consider all the benefits provided by a certain landscape and their relative importance. While the first issue is tackled by the methods described above, the second is not. This knowledge can help decision makers in two ways: on the one hand, to define the objectives of public interventions and resource allocations; on the other hand, to inform and make people aware of the values of various benefits provided by a landscape.

This paper contains the extended version of the paper presented at the ECOSUD 2015 conference by Estruch-Guitart and Vallés-Planells [26]. The focus of this work is on the relative importance of landscape aesthetics in the full value of Albufera Natural Park (Valencia). For this purpose, a method different from the ones cited above is applied. This method has been used in the economic valuation of environmental assets such as Pego-Oliva Wetland [27, 28]. Nevertheless, its application to the valuation of AE is new. The way Analytic Multicriteria Valuation Method (AMUVAM) tackles the problem of valuation differs from that of the most commonly used methods of landscape valuation. Economic value of non-market benefits under AMUVAM is obtained indirectly, by comparing the relative degrees of importance ascribed to different types of landscape values. Respondents are asked to state the importance of each of the components of the TEV by comparing them by pairs, considering AE as part of the TEV.

\section{METHODS}

Based on multicriteria analytical techniques, AMUVAM enables to determine TEV, the relative values of the components of TEV (Table 1) and the relationship between values that lack an associated market (and hence a market price) and values that do have a market price.

In AMUVAM, it is assumed that the known value of some of the components of TEV may be used to derive the values of the remaining components, such as the aesthetic value. Hence, it allows to assess (i) the relative importance and (ii) the monetary values of all the components of the TEV: direct use values (DUV), indirect use values (IUV), option/quasi-option values (OV), EV and bequest values (BV), and the disaggregated values within these components. The resulting monetary values can be interpreted as a measure of the importance attached by society, taking into account that certain sectors in society, more environmentalist and less utilitarian, consider that it is not ethic to assign a monetary value to nature.

Two techniques are involved in AMUVAM: the analytic hierarchy process (AHP) and discount cash flow analysis (DCF). AHP, the method developed by Saaty [29], which has been broadly used in different fields [30-33], is implemented to obtain the relative weights of 
Table 1: Composition of the Total Economic Value.

Total Economic Value

\begin{tabular}{|c|c|c|c|c|}
\hline \multicolumn{3}{|c|}{ Use values } & \multicolumn{2}{|c|}{ Non-use values } \\
\hline $\begin{array}{l}\text { Direct use values } \\
\text { (DUV) }\end{array}$ & $\begin{array}{l}\text { Indirect use values } \\
\text { (IUV) }\end{array}$ & $\begin{array}{l}\text { Option/quasi- } \\
\text { option values (OV) }\end{array}$ & $\begin{array}{l}\text { Existence } \\
\text { values (EV) }\end{array}$ & $\begin{array}{l}\text { Bequest } \\
\text { values (BV) }\end{array}$ \\
\hline $\begin{array}{l}\text { - Agriculture } \\
\text { - Exploitation of } \\
\text { wild flora and } \\
\text { fauna } \\
\text { - Fuel wood } \\
\text { collection } \\
\text { - Fishing } \\
\text { - Recreation } \\
\text { - Transport } \\
\text { - Peat/energy }\end{array}$ & $\begin{array}{l}\text { - Support to other } \\
\text { ecosystems } \\
\text { - Flood control } \\
\text { - Coastal stabilisa- } \\
\text { tion } \\
\text { - Microclimate } \\
\text { stabilisation } \\
\text { - Groundwater } \\
\text { recharge } \\
\text { - Retention of } \\
\text { nutrients } \\
\text { - Storm protection }\end{array}$ & $\begin{array}{l}\text { Possible future } \\
\text { uses (direct and } \\
\text { indirect) } \\
\text { - Value of the } \\
\text { information in } \\
\text { the future }\end{array}$ & $\begin{array}{l}\text { - Biodiversity } \\
\text { - Cultural } \\
\text { heritage } \\
\text { - Aesthetic } \\
\text { enjoyment }\end{array}$ & $\begin{array}{l}\text { Bequest } \\
\text { value }\end{array}$ \\
\hline
\end{tabular}

Source: adapted from Barbier et al. [38].

the TEV components, while DCF [34] is used to determine the economic values of the services associated with DUV.

The aesthetic value of a landscape may be considered as one of the values that comprise its TEV. Although this aspect of a landscape's value may be conceived as a use value rather than a non-use value [35], in this work, following previous authors [36, 37], AE is viewed as an EV.

\subsection{Site description}

The current work was developed in the Albufera de Valencia wetland. This wetlands area of 21,000 hectares, located in eastern Spain, $10 \mathrm{~km}$ from the city of Valencia, has been included in the RAMSAR Convention since 1990 and in the SPAs since 1991 and is protected under the designation of Natural Park. Moreover, due to its natural, cultural and aesthetic value, it has become a source of identity for the population of Valencia [39].

Three main ecosystems compose Albufera de Valencia: the lake, the marshland and the sandbar (Fig. 1). The name Albufera originates from the Arab term al-Buhayra (small sea), which references the lake that is the central element of this landscape. This lake originated from an ancient gulf that became enclosed as a result of sediments that were deposited into it from two rivers (Turia and Jucar River), forming a sandbar that separated the lake from the sea. The extent of the lake has changed over time, due to the development of agriculture, especially rice, which was introduced into the area in the eighteenth century. Today, the surface of the lake is approximately 2,800 hectares.

The present landscape of Albufera, is the result of centuries of human activity. There is documentary data about the use of natural resources in this area since the thirteenth century. Sanchis [40] distinguishes between two models of exploitation and water management in 


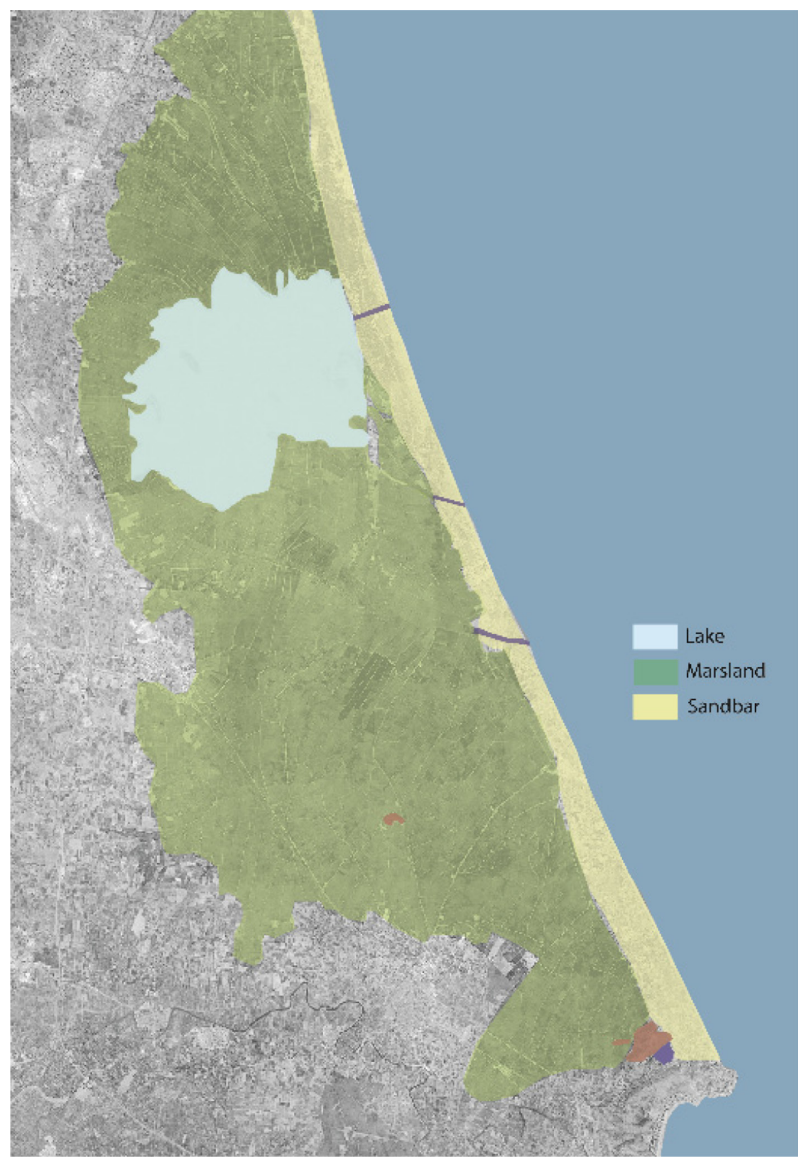

Figure 1: Main environments in Albufera Natural Park.

Albufera. The first one, between the thirteenth and the eighteenth century, was coincident with a salty Albufera lake. During this period, an extensive use of the area took place. Fishing was the main economic activity and water management was oriented towards the regulation of the reproductive cycle of fish. Rice growing in this area was marginal at that time. In the second period, approximately since the eighteenth century, agriculture became a dominant activity in Albufera, in particular the production of rice. In order to reduce the dependency of cereals from other parts of Spain (La Mancha and Aragon Regions), rice growing was allowed. Rice became, together with bread, the basis of the Valencian peoples' diet [41]. The water in the lake became fresh and it was the productive cycle of rice that guided the regulation of the water level.

However, Albufera was not just valued as a provider of goods and income. At least since the medieval age, interest in Albufera had also a component of enjoyment. As in the case of hunting. Albufera, which was a royal property until the beginning of the twentieth century, was a very well-known place for hunting by European monarchies [42]. Nowadays, hunting is still considered as a leisure activity and at the same time an economic activity, which generates revenues. Since 1987, hunting is forbidden inside the lake. But it is allowed in the surrounding area that is covered by the rice fields during the period between November and 
January. With regard to recreation and tourism in Albufera, the interest in these types of activities did not emerge until the second half of the twentieth century.

Human settlement was not significant until the end of the eighteenth century. Albufera, similarly to other wetlands, was considered a harsh environment for living due to the high risk to illnesses like paludism. El Palmar was probably the oldest settlement related to the fishermen community that worked during the week in Albufera. During the 1960s, as part of a development plan designed to promote tourism, new communications infrastructure, apartment blocks and tourist amenities were built on the sandbar that separates the lake from the sea, in the surrounding area of El Saler traditional settlement (la Devesa). This plan could not be fully implemented due to a strong movement from the population against this plan, which concluded with the environmental designation of the area as a Natural Park in 1986.

Since its environmental designation, urban pressure has slowed and regeneration works have been developed. However, problems related to water pollution [43] and the pressures of tourism persist. Meanwhile, the infeasibility of rice agriculture may result in future abandonment and degradation of this ecosystem, which occupies approximately $70 \%$ of the protected area. Today, the continuity of this area depends on payments associated with biodiversityoriented agri-environmental projects, pursuant to Council Regulation no. 1698/2005 regarding support of rural development (art. 39). Agri-environmental payments are based on the importance of the rice ecosystem in the preservation of the flora and fauna of this wetland [44] and amount to $433.62 € /$ ha applied to an area of 15,200 ha (6 $591024 €$ /year). In this context, knowledge of the TEV of the landscape would allow for a more accurate assessment of the level of investment needed in future preservation programmes.

\subsection{Definition of the TEV components}

According to Barbier [45], the value of a wetland is derived from its assets, flows and attributes. Assets, also called products, goods or stocks, are those components that are directly exploitable by humans and provide economic benefit. Flows or services refer to the ways in which ecosystem processes contribute to human well-being. They usually refer to environmental regulating services (flood control, erosion prevention etc), but also refer to recreational and cultural benefits derived from nature. Hence they involve material and immaterial benefits for humans. Nowadays, both goods and services are included under the umbrella of ecosystem services [46]. With regard, to the third concept, attribute, it refers to those components of a wetland that have value because they induce certain economic uses or they have value in themselves (e.g. biodiversity, cultural heritage). Taking into account these components of a wetland value, Barbier [45] proposed the concept of TEV, which distinguishes between use and non-use values.

The TEV components and their associated goods, services and attributes for the case study of Albufera Natural Park (Table 2) were based on previous work on economic valuation of wetlands, on the study area and on the discussion with experts [47] that would also take part in the weight assignment stage (Section 2.3).

a) Use values

a1) DUV usually refer to the values derived from the goods that can be extracted, consumed or enjoyed directly. In this work, they correspond to the goods that involve the consumption of natural resources and have a market value. They are rice production, hunting and fishing. 
Table 2: Components of TEV in Albufera of Valencia.

\begin{tabular}{ll}
\hline Values & Activities and/or functions \\
\hline DUV & Rice growing, hunting, fishing \\
IUV & $\begin{array}{l}\text { Support of other ecosystems, flood control, coastal stabilisation, groundwater } \\
\text { recharge, retention of nutrients, recreation }\end{array}$ \\
OV & Possible future uses (direct and indirect); value of information in the future \\
EV & Biodiversity; cultural heritage; aesthetic enjoyment \\
BV & Bequest value
\end{tabular}

DUV: direct use values; IUV: indirect use values; OV: option, quasi-option values; BV: bequest values; EV: existence values.

a2) IUV are mainly derived from the services ecosystems produce. In this work, together with flood control, groundwater recharge, retention of nutrients and support to other ecosystems, included in the classification of wetlands by Barbier [45], coastal stabilisation and recreation have been considered. The dunes system in Albufera Natural Park reduces the erosion of the coastline. In terms of recreation, cycling, birdwatching, walking, boating, swimming and sunbathing are some of the main recreational activities in this area. These latter activities - recreational - which could be connected to tourism, are not considered as a direct use of a non-consumptive good [48] since it is assumed that revenues are connected with the services provided by touristic enterprises that take advantage of the Natural Park as the environment for their activity.

a3) OV is associated to the fact that the future value is uncertain. It relates to the importance attached to maintaining the option to take advantage of the wetland use value in the future even if it seems unimportant now. It is related to the expected value of the information derived from delaying use. Following De Groot et al. [49], all the services mentioned above (in its broad sense, goods and services) can be considered within this component of TEV.

b) Non-use values

b1) EV are the values of the wetland in their own right. It is related to the importance attached to the knowledge that something exists. Together with biodiversity and cultural heritage, AE has been considered [36, 37].

b2) BV or LV refers to the possibility of future generations using and enjoying the wetland. Similar to OV all the services can be included in this group.

\subsection{Weight assignment of TEV components by experts}

In this step, AHP [29] is implemented in order to obtain the relative weights of TEV components and EV components from a group of experts. They must have a deep knowledge of the area and represent the different points of view on the wetland.

Experts weight components at two levels (Fig. 2). They start weighing TEV components (level 1) and then, they weigh EV components (level 2). The survey starts with a brief explanation of the goal of the work and the meaning of the different types of values. Then, experts are asked to compare TEV and EV components by pairs. This comparison is implemented in two steps. First, they decide which of the two components is the most important (Table 3). The question posed to the participants is the following: of the two values being compared, 


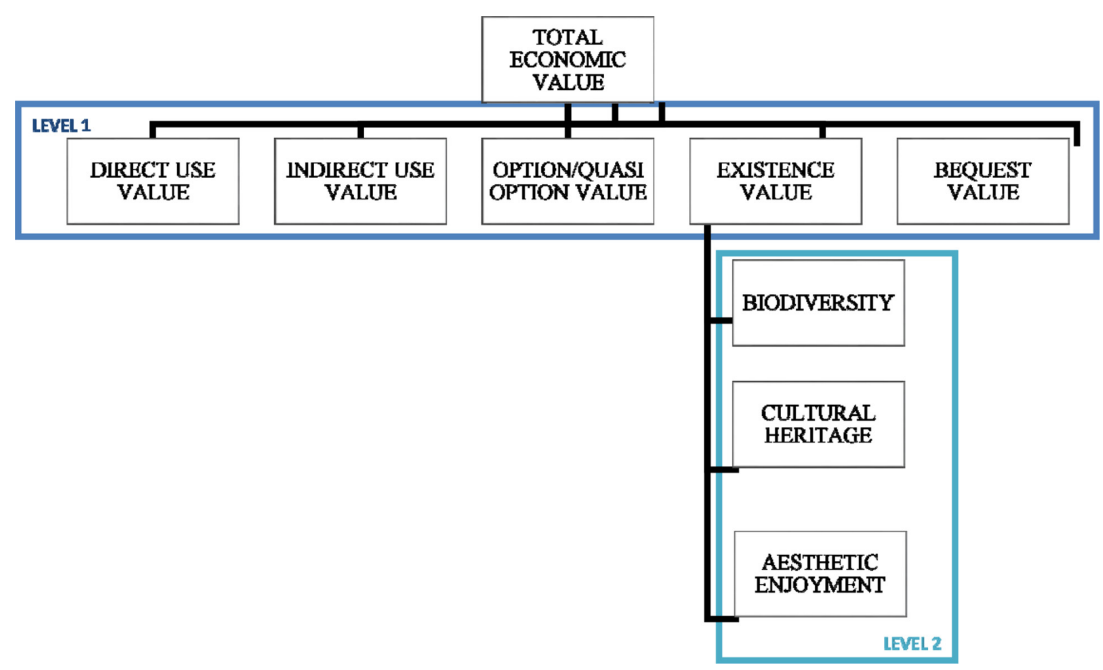

Figure 2: Diagram showing TEV and EV components compared during the survey.

Table 3: Comparison between TEV components.

\begin{tabular}{lc}
\hline Comparison & Scores \\
\hline DIRECT USE/INDIRECT USE values & $/$ \\
DIRECT USE/OPTION, QUASI-OPTION values & $/$ \\
DIRECT USE/EXISTENCE values & $/$ \\
DIRECT USE/BEQUEST values & $/$ \\
INDIRECT USE/OPTION, QUASI-OPTION values & $/$ \\
INDIRECT USE/EXISTENCE values & $/$ \\
INDIRECT USE/BEQUEST values & $/$ \\
OPTION, QUASI-OPTION VALUES/EXISTENCE values & $/$ \\
OPTION, QUASI-OPTION VALUES/BEQUEST values & $/$ \\
EXISTENCE/BEQUEST values & \\
\hline
\end{tabular}

which is considered more important by society with respect to the overall value of Albufera Natural Park? Second, they express the intensity of importance, using the scale of comparisons shown in Table 4. According to how close the elements compared in importance are, one can use the different values of the fundamental scale.

Their answers are used to obtain the comparison matrices. There are as many matrices as consulted stakeholders. The consistency ratios (CR) are then verified, and eigenvalues are calculated. Finally, the geometric mean of the eigenvalues is calculated [29] to obtain the weights of the various TEV and EV components.

For this study, the set of experts included local and external stakeholders representing the key topics of the area, in terms of exploitation and conservation of natural resources. Experts were representatives of:

- Albufera Technical Office, in charge of the Natural Park management

- Valencia Regional Agricultural department 
Table 4: The fundamental scale for pairwise comparisons.

\begin{tabular}{lll}
\hline Scale & Definition & Explanation \\
\hline 1 & Equal importance & $\begin{array}{l}\text { Two elements contribute equally to the property or } \\
\text { criterion } \\
3\end{array}$ \\
Moderate importance & $\begin{array}{l}\text { Experience and judgement slightly favour one } \\
\text { element over another } \\
\text { Strong importance }\end{array}$ & $\begin{array}{l}\text { Experience and judgement strongly favour one } \\
\text { element over another }\end{array}$ \\
7 & Very strong importance & $\begin{array}{l}\text { Experience and judgement very strongly fa- } \\
\text { vour one element over another; its dominance is } \\
\text { demonstrated in practice } \\
\text { The evidence favouring one activity over another } \\
\text { is of the highest possible order of affirmation }\end{array}$ \\
\hline
\end{tabular}

Source: Saaty [29].

- Valencia Regional Environmental departments related to natural environment and landscape sections

- Farmer trade associations

- Irrigation community

- Fishing community

- Rice cooperatives

- Ecologist associations

- University lecturers specialised in landscape planning, botanic and phitotecnics

In this study, TEV weights were derived from the responses of 43 experts conducted during two surveys, a previous one in 2005 (25 experts) and another in 2012 (18 experts). EV weights were obtained from the 18 experts consulted in 2012. The incorporation of the data obtained in a previous study in 2005 allowed comparison of the values of the TEV components.

\subsection{Calculation of the pivot value}

This stage aims to obtain the economic value, called the pivot, of a TEV component. The DUV is usually the pivot because it associates economic functions with market values. The pivot value is based on both present and future revenues derived from the exploitation of these resources. DCF is a method of valuation based on the revenues an asset generates over a period of time [34]. This method assumes that the economic value of an asset corresponds to the present value of the sum of the future revenues derived from this asset. In this way, the present value of future expected net cash flows is calculated using a discount rate that converts a future monetary sum into present value. In this case, the pivot value is derived from rice, hunting and fishing activities. First, the annual revenues derived from the incomes and expenditures of these three activities are calculated. Then, following Evans [50], this cash flow is updated applying a 3\% tax (eqn (2)). Discount rate (DR) (eqn (1)) was estimated for 2011 from the following data: $\mathrm{p}$ data (individual or pure temporal preference tax in \%) for 20082011 [51]; g data (expected task of the increase of consumption per capita) for 1982-2011 [52] and e data (elasticity of the marginal utility curve of consumption) for 2011 [53, 54]. 
The formula to calculate the social discount rate based on the social time preference is given by the Ramsey equation [55].

$$
\begin{gathered}
\qquad D R=p+e \times g \\
\text { DUV value }=\frac{\text { Cash flow of the services provided by DUV }}{\text { Discount rate }}
\end{gathered}
$$

\subsection{Calculation of the TEV and its related components}

The hypothesis behind the TEV as the sum of its partial components is implicit in this stage. This approach has been argued by different authors [56-58]. However, if the TEV is not considered a market value, but an indicator of the value of an environmental asset, the sum of its partial values may be seen as an estimate of its real value [59-62].

Once the pivot is known, the values of the other TEV components (IUV, OV, EV, BV) are estimated, using the eigenvalue determined through the AHP method, so that the relative weights of the TEV components are defined (eqns (3)-(6)). The TEV of the environmental asset is then determined by adding up all the partial values (eqn (7)). The value thus obtained indicates the TEV of the Albufera landscape. Then, the value of each EV component (biodiversity, cultural heritage and AE) is derived from their weights and the known economic value of the EV (eqn (8)-(10)).

$$
\begin{gathered}
\mathrm{IUV}=\frac{D U V}{D U V \text { weight }} \times I U V \text { weight } \\
\mathrm{O} / \mathrm{OV}=\frac{\mathrm{DUV}}{\mathrm{DUV} \text { weight }} \times \mathrm{O} / \mathrm{OV} \text { weight } \\
\mathrm{EV}=\frac{\mathrm{DUV}}{\mathrm{DUV} \text { weight }} \times \mathrm{EV} \text { weight } \\
\mathrm{BV}=\frac{\mathrm{DUV}}{\mathrm{DUV} \text { weight }} \times \mathrm{BV} \text { weight } \\
\mathrm{TEV}=\mathrm{DUV}+\mathrm{IUV}+\mathrm{O} / \mathrm{OV}+\mathrm{EV}+\mathrm{BV} \\
\mathrm{BV}=\mathrm{EV} \times \mathrm{B} \text { weight } \\
\mathrm{CH} \text { value }=\mathrm{EV} \times \mathrm{CH} \text { weight } \\
\mathrm{AE} \text { value }=\mathrm{EV} \times \mathrm{AE} \text { weight }
\end{gathered}
$$

\subsection{Analysis of expert valuations}

Once average values are obtained for the TEV and EV components, this stage focuses on the analysis of the differences among the weights assigned to these components by the experts. For this purpose, first a cluster analysis is implemented and, then, a variance analysis is applied in order to check if there are significant statistical differences among the groups. 
Cluster analysis produces hierarchical groups of items based on distance measures of dissimilarity or similarity. The variables used are, firstly, the components of TEV and, secondly, the components of EV. Euclidean distance is used to calculate the distance between two items and the clustering method is the method of average linkage between groups [63].

Significant statistical differences among the groups derived from the cluster analysis of TEV components are estimated through the $t$-test. It compares sample means by calculating Student's t and displays the two-tailed probability. TEV components are considered the dependent variables whereas the variable obtained from cluster analysis is the independent variable. Variance analysis (ANOVA) is applied for EV components. In particular, one-way analysis is implemented which produces a one-way analysis of variance for an interval-level dependent variable by one numeric independent variable that defines the groups for the analysis. EV components are assumed where the dependent variables and the variable derived from cluster analysis is the independent variable. Post hoc analysis which tests for comparisons of all possible pairs of group means or multiple comparisons is Bonferroni t test. This test is based on Student's t statistic and adjusts the observed significance level for the fact that multiple comparisons are made.

\section{RESULTS}

\subsection{Calculation of the TEV components}

The survey was carried out in August, September and October of 2005 and in October 2012 with completion time for the survey averaging 25 minutes. The pairwise comparisons made by the experts were used to calculate the eigenvalues, which indicated the relative importance, from the experts' points of view, of each TEV component. The consistent matrices (derived from the 34 experts whose CR did not exceed 10\%) were used to calculate the aggregated eigenvalue, which was estimated by calculating the geometric mean of the eigenvalues and was normalised by addition (Table 5).

Table 6 shows incomes and expenditures associated with these activities. After updating the calculated cash flow to account for a 3\% tax [50], the estimated DUV in Albufera was $€ 333$ million. With regard to the TEV, Table 7 shows the global value and the values corresponding to the two groups derived from cluster analysis.

Table 5: Aggregated and normalised eigenvalues.

\begin{tabular}{lc}
\hline TEV & Weights of TEV Components \\
\hline DUV & 0.1375 \\
IUV & 0.1882 \\
OV & 0.0822 \\
EV & 0.2979 \\
BV & 0.2942 \\
\hline
\end{tabular}

TEV: total economic value; DUV: direct use values; IUV: indirect use values; OV: option, quasi-option values; BV: bequest values; EV: existence values. 
Table 6: Incomes and expenditures (€) related to the components of direct use values.

\begin{tabular}{llll}
\hline & Incomes & Expenditures & Cash Flow \\
\hline Rice & 49645706 & 40001538 & 9644168 \\
Hunting & 598564 & 390902 & 207662 \\
Fishing & 306595 & 154920 & 151675 \\
Total & 50550865 & 40547360 & 10003505 \\
\hline
\end{tabular}

Table 7: Albufera economic value according to the aggregated weights assigned by experts.

\begin{tabular}{|c|c|c|c|c|c|c|c|c|c|}
\hline \multirow[t]{3}{*}{ TEV } & \multicolumn{3}{|c|}{$\begin{array}{l}\text { Weights of TEV } \\
\text { components }\end{array}$} & \multicolumn{3}{|c|}{ Value in $1,000 €$} & \multicolumn{3}{|c|}{$\begin{array}{l}\text { Value Flow in } 1,000 / \\
\text { year }\end{array}$} \\
\hline & Cluster & Cluster & & & & & Cluster & Cluster & \\
\hline & 1 & 2 & Global & Cluster 1 & Cluster 2 & Global & 1 & 2 & Global \\
\hline UDV & 0.0636 & 0.3285 & 0.1375 & 333,450 & 333,450 & 333,450 & 10,003 & 10,003 & 10,003 \\
\hline UIV & 0.1216 & 0.2620 & 0.1882 & 637,931 & 266,014 & 456 & 19,138 & 7,980 & 13,698 \\
\hline $\mathrm{OV}$ & 0.0489 & 0.1307 & 0.0822 & 256,673 & 132,632 & 199,410 & 7,700 & 3,979 & 5,982 \\
\hline $\mathrm{EV}$ & 0.4358 & 0.1107 & 0.2979 & $2,285,896$ & 112,423 & 722,540 & 68,577 & 3,373 & 21,676 \\
\hline $\mathrm{BV}$ & 0.3300 & 0.1681 & 0.2942 & $1,730,864$ & 170,609 & 713,700 & 51,926 & 5,118 & 21,411 \\
\hline & & & & $5,244,814$ & $1,015,127$ & $2,425,694$ & 157,344 & 30,454 & 72,771 \\
\hline
\end{tabular}

TEV: total economic value; DUV: direct use values; IUV: indirect use values; OV: option, quasi-option values; BV: bequest values; EV: existence values.

\subsection{Calculation of the EV components}

Based on the geometric mean of the 15 consistent matrices and the EV estimated in the preceding section, the economic values of these three components were calculated. Tables 8 and 9 show the relative importance of these three components and their economic value for the whole group as well as for the three groups derived from cluster analysis. The assessed value of AE in Albufera Natural Park is $€ 146$ million ranging between $€ 86$ and 186 million.

Table 8: Albufera EV according to the aggregated weights assigned by experts (value in $1,000 €)$.

\begin{tabular}{lllllllll}
\hline \multicolumn{4}{c}{ Weights of TEV components } & \multicolumn{3}{c}{ Value in 1,000€ } \\
\hline EV & \multicolumn{9}{c}{0,2979} \\
\hline & Cluster 1 & Cluster 2 & Cluster 3 & Global & Cluster 1 & Cluster 2 & Cluster 3 & Global \\
\hline B & 0.62 & 0.77 & 0.10 & 0.55 & 450,07 & 559,30 & 75,65 & 399,49 \\
CH & 0.13 & 0.11 & 0.64 & 0.20 & 91,92 & 81,62 & 460,25 & 147,07 \\
AE & 0.25 & 0.11 & 0.26 & 0.24 & 180,55 & 81,62 & 186,63 & 175,99 \\
\hline
\end{tabular}


Table 9: Albufera EV according to the aggregated weights assigned by experts (value flow in $1,000 € /$ year).

\begin{tabular}{lllllllll}
\hline & \multicolumn{3}{c}{ Weights of TEV components } & \multicolumn{3}{c}{ Value Flow in 1,000 €/year } \\
\hline EV & \multicolumn{4}{c}{0,2979} \\
\hline & Cluster 1 & Cluster 2 & Cluster 3 & Global & Cluster 1 & Cluster 2 & Cluster 3 & Global \\
\hline B & 0.62 & 0.77 & 0.10 & 0.55 & 13,50 & 16,78 & 2,27 & 11,99 \\
CH & 0.13 & 0.11 & 0.64 & 0.20 & 2,76 & 2,45 & 13,81 & 4,41 \\
AE & 0.25 & 0.11 & 0.26 & 0.24 & 5,42 & 2,45 & 5,60 & 5,28 \\
\hline
\end{tabular}

\section{DISCUSSION}

This work has shown how the AMUVAM method can provide knowledge about the importance of the aesthetic value of a landscape in comparison with the other components of the TEV. According to the results, the aesthetic value of a landscape corresponds to $7 \%$ of the TEV and $24 \%$ of the EV in Albufera Natural Park (€176 million).

However, the statistical analysis of expert weights also reveals the existence of distinct patterns in the valuation of TEV and EV components. These differences in weight assignment may be attributed to the existence of different interests and attitudes towards the valued asset. This finding is in agreement with those of previous authors working in the field of land management who have reported differences in weight assignment among different expert groups [31]. In this way, this study provides, together with the average value, a range of values that reflect the different sensitivities of society for the TEV and its components.

Regarding the TEV, cluster analysis suggests two different patterns - environmentalist and utilitarian [64] - which show significant statistical differences for all the components of the TEV (Table 7). The utilitarian group (cluster 1, corresponding to $62 \%$ of the participants) gives a higher importance to use values that represent $72 \%$ of the TEV, while non-use values correspond to $77 \%$ of the TEV according to the environmentalist group (cluster 2, corresponding to $38 \%$ of the participants). According to this analysis, the TEV of Albufera Natural Park ranges between $€ 1.015$ and $€ 5.244$ billion.

Despite the lack of consensus in the importance of the different components of the TEV, it is noted that all the TEV components receive similar weights in both surveys (2005 and 2012) except for the BV (Fig. 3). Unfortunately, this comparison could not be conducted for the aesthetic value, since no data about the EV components was collected in 2005.

With regard to $\mathrm{EV}$, results suggest that the weight assigned to $\mathrm{AE}$ ranges between $11 \%$ and $26 \%$ of the EV, which corresponds to $3.56 \%$ and $7.61 \%$ of the TEV. Three different groups have been identified (Table 8). These groups show a double approach towards Albufera. The first two clusters (corresponding to $53 \%$ and $27 \%$ of the participants) represent the group of people that place more importance to the ecologic values of Albufera. This is the expected outcome in an area with international and regional legal recognition of its ecological values (it is included in the RAMSAR Convention and in the SPAs and it is protected under the designation of Natural Park) which is one of the few areas with environmental value in the proximity of Valencia City. These two clusters just differ on the value placed on AE. The weight of AE in the first cluster (25\%) is twice as high as in the second cluster (11\%). Secondly, the third cluster (corresponding to $20 \%$ of the participants) represent the cultural 


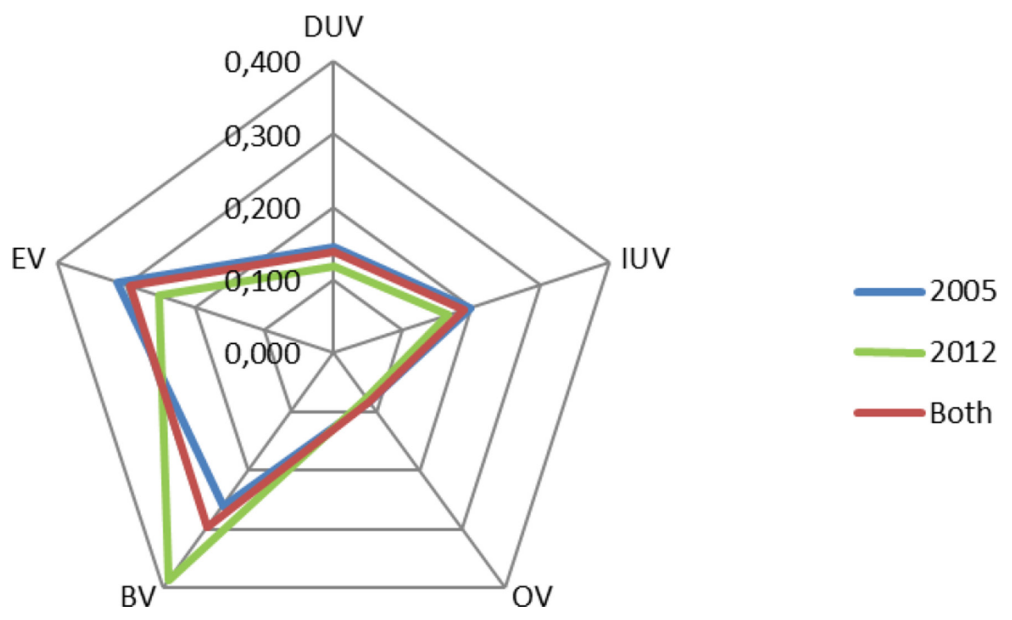

Figure 3: Weights of TEV components in surveys conducted in 2005 and 2012.

approach to Albufera. This second group can be explained by the fact that Albufera, unlike other wetlands, has been traditionally linked to human activity and it is part of the imaginary and identity of Valencian society [40].

\subsection{Comparison with previous works}

In order to test the consistency between valuations proposed in this study and those of other studies, two studies in which average economic values were derived are used for comparison with our results. For this purpose, it was necessary to calculate the TEV in terms of dollars per ha. This value must be understood just as an estimate to corroborate the magnitude of the results obtained in this work. Since, in agreement with previous works, we believe that comparison of valuations developed in different geographical areas is difficult and doubtful because of the influence of the biophysical and socioeconomic context, the method of valuation and the aspects considered [65-67]. Moreover, we assume that certain components of the TEV like aesthetics are especially dependent on landscape type and traits and do not show a linear dependency with size.

On the one hand, the work of De Groot et al. [49] provides an average value of 3,274 US $\$ /$ ha/year, derived from 200 studies of wetlands. Their study is a synthesis of work developed by Schuijt and Brander [68] (calibrated for 2000) and Costanza et al. [36] (calibrated for 1994). This value does not account for such services as ornamental and medicinal resources, historic and spiritual values or sediment control. On the other hand, Brenner et al. [69] provide an average value of $\$ 3,463 /$ ha/year for the non-market benefits of the coastal zone of Catalonia (calibrated for 2004), based on a spatial value transfer assessment. Brenner et al. [69] also show average value by county. For the counties of the Ebro River Delta - a Ramsar wetland that has certain similarities with the Albufera wetland, in terms of natural ecosystem type and human land use - they estimate a range of values between $\$ 3,672$ and $\$ 4,123 /$ ha/year. Comparison of the various studies considered (Table 10) shows that the TEV of Albufera Natural Park, 4,314 US\$/ha yr (standardiszed to 2005), exceeds the estimates obtained for similar areas in the other studies, but nevertheless is similar in scale. This higher result in the present study may be explained, in part, 
Table 10: Comparison of valuation studies developed in similar landscapes.

\begin{tabular}{|c|c|c|c|c|c|c|}
\hline & $\begin{array}{l}\text { De Groot } \\
\text { et al. } \\
{[43]^{(1)}}\end{array}$ & $\begin{array}{l}\text { Brenner and } \\
\text { Raiffa } \\
{[57]^{(2)}}\end{array}$ & $\begin{array}{l}\text { Albufera } \\
\text { standardised } \\
\text { to } 2005 \\
\mathrm{USD}^{(3)}\end{array}$ & $\begin{array}{l}\text { Albufera } \\
\text { standardised } \\
\text { to } 2004 \\
\mathrm{USD}^{(4)}\end{array}$ & $\begin{array}{l}\text { Albufera } \\
\text { standardised } \\
\text { to } 2000 \\
\text { USD }^{(5)}\end{array}$ & $\begin{array}{l}\text { Albufera } \\
\text { standardised } \\
\text { to } 1994 \\
\mathrm{USD}^{(6)}\end{array}$ \\
\hline $\begin{array}{l}\text { Value in } \\
\text { USD/ha yr }\end{array}$ & 3,274 & $3,672-4,123$ & 4,314 & 4,453 & 3,768 & 3,071 \\
\hline
\end{tabular}

(1) TEV of the main ecosystem services provided by wetlands derived from Schuijt \& Brander 2004 (standardised to 2000) and Costanza et al. 1997 (standardised to 1994) covering over 200 case studies.

(2) Range of ecosystem service values (ESV) (standardised to 2004) in Baix Ebre and Montsià counties corresponding to Delta Ebre derived from those ecosystem services that are not part of existing economic markets.

(3) $1 €=1.244982$ US\$

(4) $1 €=1.243060$ US $\$$

(5) $1 €=0.924087$ US\$

(6) $1 €=1.201579$ US\$

by the fact that some of the values included in this work are not considered in the studies cited for comparison. For instance, historic values are not taken into account in De Groot et al. [49], and direct values that have associated markets are not considered in Brenner et al. [69].

\subsection{AMUVAM as a basis for a better allocation of resources}

The fact that valuation in AMUVAM is comparison-based also allows us to gain knowledge about the relationships among the different components of the TEV. Implementation of this method allows comparisons not only between the values of various benefits provided by a landscape, but also between different budgetary items. In particular, our results show that the value derived from agri-environmental projects for the maintenance of biodiversity in the study area (433.62 €/ha) approaches the estimated value of the biodiversity (570€/ha) of this area. But no economic support is allocated to the maintenance of the aesthetic quality of the landscape, which involves half of the value of biodiversity.

\subsection{Further research}

This study does not include the benefits derived from tourism as part of DUV. The provision of tourism and recreation activities in Albufera Natural Park is conceived as IUV. Behind this decision is the idea of connecting the DUV with the provision of goods. However, if the meaning of DUV would be extended to those functions with a market value, then tourism could be considered as part of the DUV. In this way, it would be worthwhile to explore the effects of including the benefits of tourism in the DUV in further research. Other interesting areas for further research would be working in methods for reducing variability and building consensus in weigh assignment of TEV components and estimating the monetary value of aesthetics in different landscape types. 


\section{CONCLUSIONS}

The economic valuation of the full set of goods and services is an important issue when defining environmental policies. However, the intangible character of the functions provided by landscape and its complex interpretation make it difficult to establish an economic value that shows its importance. Therefore, the economic valuation of landscape does not make sense as a goal in itself but as an indicator for managers and stakeholders to take better-informed decisions in the context of planning and management.

This paper makes use of AMUVAM methodology to address the issue of the economic valuation of AE, as part of the TEV. Unlike other methods that only focus on the value of some of the partial aspects of the TEV, the main contribution of AMUVAM is the estimation of both the TEV and the partial values associated with its components (DUV, IUV, OV, $\mathrm{BV}$ and EV). Other important aspects of AMUVAM are the ability to test the consistency of the information given by each expert using the CR and to enable the involvement of a group of individuals in the definition of the relative importance of the different values considered.

Regarding the limitations to the application of the AMUVAM, its main weakness is related to the level of knowledge required by the experts. Experts should have a thorough knowledge of the asset in question, allowing them to make credible comparisons, a broad understanding of the functions involved in each value and knowledge of the procedures and the importance and purpose of the comparisons.

In this work, the proposed method is applied to the Albufera Natural Park (Valence, Spain), which is a 21,000 hectares wetland that is included in the RAMSAR Convention and in the SPAs. After identifying the set of functions provided by this landscape, including the AE of landscape as a function within the EV, a group of experts defined the relative importance of each of the TEV and EV components. Then, knowing the economic value of the productive activities that take place in this area (rice growing, hunting and fishing) and that have an associated market value, the economic value of the rest of the components is obtained, and an estimation of $\mathrm{AE}$ in economic terms is established as $€ 176$ million and its range as being between $€ 82$ and 187 million. This range of values corresponds to the different patterns of valuation identified in this study, which reflect the diversity of sensitivities within a society with regard to the components of TEV. Finally, the comparison of the TEV of Albufera Natural Park with previous economic valuations conducted in other wetlands reveal a similarity in scale.

\section{REFERENCES}

[1] Termorshuizen, J.W. \& Opdam P., Landscape services as a bridge between landscape ecology and sustainable development. Landscape Ecology, 24, pp. 1037-1052, 2009. https://doi.org/10.1007/s10980-008-9314-8

[2] De Groot, R., Function-analysis and valuation as a tool to assess land use conflicts in planning for sustainable, multi-functional landscapes. Landscape and Urban Planning, 75(3-4), pp. 175-186, 2006.

https://doi.org/10.1016/j.landurbplan.2005.02.016

[3] Antrop, M., Sevenant, M., Tagliaferro, C., Van Eetvelde, V. \& Witlox, F., Setting a framework for valuing the multifunctional landscape and its multiple perceptions. The Economic Value of Landscapes, ed. W. Heijman \& M. van der Heide, Routledge, pp. 23-52, 2012. 
[4] Swanwick, C., Hanley, N. \& Termansen, M., Scoping study on Agricultural Landscape Evaluation. Final Report to DEFRA, University of Leeds, The University Of Sheffield \& University of Stirling, 2007.

[5] Daniel, T.C., Wither scenic beauty? Visual landscape quality assessment in the 21st century. Landscape and Urban Planning, 54(1-4), pp. 267-281, 2001. https://doi.org/10.1016/S0169-2046(01)00141-4

[6] Daniel, T.C. \& Boster, R.S., Measuring Landscape Aesthetics: the Scenic Beauty Estimation Method, ASDA For. Ser., RMFRES, Colorado, USA, Research Paper RM 167, 1976.

[7] Bourasa, S.C., The Aesthetics of Landscape, Belhaven Press: London, 1991.

[8] Kaplan, R. \& Kaplan, S., The Experience of Nature: A Psychological Perspective, Cambridge University Press, New York, 1989.

[9] Lothian, A., Landscape and the philosophy of aesthetics: is landscape quality inherent in the landscape or in the eye of the beholder? Landscape and Urban Planning, 44(4), pp. 177-198, 1999. https://doi.org/10.1016/S0169-2046(99)00019-5

[10] Steinitz, C., Visual evaluation models: some complicating questions regarding memorable scenes. Landscape and Urban Planning, 54, pp. 283-287, 2001. https://doi.org/10.1016/S0169-2046(01)00142-6

[11] Arriaza, M., Canas-Ortega, J.F., Canas-Madueno, J.A. \& Ruiz-Aviles, P., Assessing the visual quality of rural landscapes. Landscape and Urban Planning, 69, pp. 115-125, 2004. https://doi.org/10.1016/j.landurbplan.2003.10.029

[12] Kangas, J., Laasonen, L. \& Pukkala, T., A method for estimating forest landowner's landscape preferences. Scandinavian Journal of Forest Research, 8, pp. 408-417, 1993. https://doi.org/10.1080/02827589309382787

[13] Fontana, V., Radtke, A., Fedrigotti, V.B., Tappeiner, U., Tasser, E., Zerbe, S. \& Buchholz, T., Comparing land-use alternatives: using the ecosystem services concept to define a multi-criteria decision analysis. Ecological Economics, 93, pp. 128-136, 2013. https://doi.org/10.1016/j.ecolecon.2013.05.007

[14] Pukkala, T., Nuutinen, T. \& Kangas, J., Integrating scenic and recreational amenities into numerical forest planning. Landscape and Urban Planning, 32, pp. 185-195, 1995. https://doi.org/10.1016/0169-2046(94)00195-9

[15] Fines, K.D., Landscape evaluation: a research project in East Sussex. Regional Studies, 2(1), pp. 41-55, 1968. https://doi.org/10.1080/09595236800185041

[16] Price, C., Landscape economics at dawn: an eye-witness account. Landscape Research, 33(3), pp. 263-280, 2008.

https://doi.org/10.1080/01426390802045897

[17] Price, C., Landscape Economics. MacMillan Press: London, 1978. https://doi.org/10.1007/978-1-349-03747-6

[18] Oueslati, W. \& Salanié, J., Landscape valuation and planning. Journal of Environmental Planning and Management, 54(1), pp. 1-6, 2011. https://doi.org/10.1080/09640568.2010.505771

[19] Bergstron, J.C., Stoll, J.R., Titre, J.P. \& Wright V.L., Economic value of wetlands-based recreation. Ecological Economics, 2, 129-147, 1990.

https://doi.org/10.1016/0921-8009(90)90004-E 
[20] Kong, F., Yin, H. \& Nakagoshi, N., Using GIS and landscape metrics in the hedonic price modeling of the amenity value of urban green space: a case study in Jinan City, China. Landscape and Urban Planning, 79, pp. 240-252, 2007. https://doi.org/10.1016/j.landurbplan.2006.02.013

[21] Luttik, J., The value of trees, water and open space as reflected by house prices in the Netherlands. Landscape and Urban Planning, 48(3-4), pp. 161-167, 2000. https://doi.org/10.1016/S0169-2046(00)00039-6

[22] Lange, E. \& Schaeffer, P.V., A comment on the market value of a room with a view. Landscape and Urban Planning, 55, pp. 113-120, 2001. https://doi.org/10.1016/S0169-2046(01)00148-7

[23] Hanley, N., Wright, M., Bullock, R.E., Simpson, I., Parsisson, D. \& Crabtree, B., Contingent valuation versus choice experiments: estimating the benefits of environmentally sensitive areas in Scotland. Journal of Agricultural Economics, 49(1), pp. 1-15, 1998. https://doi.org/10.1111/j.1477-9552.1998.tb01248.x

[24] Hynes, S., Campbell, D. \& Howley, P., A holistic vs. an attribute-based approach to agri-environmental policy valuation: Do welfare estimates differ? Journal of Agricultural Economics, 62(2), pp. 305-329, 2011. https://doi.org/10.1111/j.1477-9552.2010.00287.x

[25] Moran, D., The economic valuation of rural landscapes. SEERAD, Edinburg. Research Study AA211, 2005, available at http://www.snh.org.uk/pdfs/strategy/landscapes/ Annex.pdf (accessed 1 February 2013).

[26] Estruch-Guitart, V. \& Vallés-Planells, M., The role of landscape aesthetics in the total economic value of landscape: a case study of albufera natural park. WIT Transactions on Ecology and the Environment, 192, pp. 1-12, 2015. https://doi.org/10.2495/eco150201

[27] Aznar, J. \& Estruch, V., Environmental assets valuation through multicriteria methods. Implementation in the valuation of Alto Tajo Natural Park (Valoración de activos ambientales mediante métodos multicriterio. Aplicación a la valoración del Parque Natural del Alto Tajo). Economía Agraria y Recursos Naturales, 7(13), pp. 107-126, 2007 (in Spanish). https://doi.org/10.7201/earn.2007.13.06

[28] Aznar, J., Estruch, V. \& Vallés, M., Valuation of environmental assets by the multicriteria AMUVAM method and its application to the Pego-Oliva wetland. Environmental Engineering and Management Journal, 13(3), 1535-1547, 2014.

[29] Saaty, T., The Analytic Hierarchy Process: Planning, Priority Setting, Resource Allocation, RWS Publications: Pittsburgh, 1980.

[30] Boucher, T.O. \& MacStravic, E.L., Multiattribute evaluation within a present value framework and its relation to the analytic hierarchy process. The Engineering Economist, 37(1), 1-32, 1991. https://doi.org/10.1080/00137919108903055

[31] Chow, T.E. \& Sadler, R., The consensus of local stakeholders and outside experts in suitability modeling for future camp development. Landscape and Urban Planning, 94, pp. 9-19, 2010. https://doi.org/10.1016/j.landurbplan.2009.07.013

[32] Kangas, J. 1993. A multiattribute preference model for evaluating the reforestation chain alternatives of a forest stand. Forest Ecology and Management, 59, pp. 271-288. https://doi.org/10.1016/0378-1127(93)90007-A 
[33] Maroto, C., Segura, M., Ginestar, C., Uriol, J. \& Segura, B., Sustainable forest management in a Mediterranean region: social preferences. Forest Systems, 22(3), pp. 546-448, 2013. https://doi.org/10.5424/fs/2013223-04135

[34] IVSC, International Valuation Standards 2001, International Valuation Standards Committee: London, 2001.

[35] Swanwick, C., Hanley, N. \& Termansen, M., Scoping study on agricultural landscape evaluation. Final Report to DEFRA, University of Leeds, The University Of Sheffield \& University of Stirling, 2007.

[36] Costanza, R., d'Arge, R., de Groot, R., Farber, S., Grasso, M., Hannon, B., Limburg, K., Naeem, S., O’Neill, R.V., Paruelo, J., Raskin, R.G., Sutton, P. \& Van Den Belt, M., The value of the world's ecosystem services and natural capital. Nature, 387, pp. 253-260, 1997.

https://doi.org/10.1038/387253a0

[37] De Groot, R., Wilson, M.A. \& Boumans, R.M.J., A typology for the classification, description and valuation of ecosystem functions, goods and services. Ecological Economics, 41(3), pp. 393-408, 2002.

https://doi.org/10.1016/S0921-8009(02)00089-7

[38] Barbier, E.B., Acreman, M.C. \& Knowler, D., Economic valuation of wetlands: A guide for policy makers and planners. Ramsar Convention Bureau, Department of Environmental Economics and Environmental Management, University Of York, Institute of Hydrology, IUCN-The World Conservation Union, Gland, Switzerland, 1997.

[39] Sanchis, C., The construction of a landscape icon. The Albufera of Valencia (18891939) (La construcció d’una icona paisatgística. L'Albufera de València (1889-1939)). SAITABI, 57, pp. 241-260, 2007 [in Catalan].

[40] Sanchis, C., Regadiu i Canvi Ambiental a l'Albufera de València (Irrigation and Environmental Change in Albufera de Valencia), Universitat de València: Valencia, 2010 [in Catalan].

[41] Bueno, R. \& Jiménez, R., Crónicas de arroz, mosquitos y paludismo en España: el caso de la provincia de Valencia (s. XVIII-XX) (Chronicles of rice, mosquitoes and malaria in Spain: the case of the Province of Valencia (18th-20th centuries). Hispania, vol. LXX, 236, pp. 687-708, 2010 [in Spanish]. https://doi.org/10.3989/hispania.2010.v70.i236.329

[42] Rosselló, V.M., L’Albufera de València, L’Abadia de Montserrat, Barcelona, 1995 [in Catalan].

[43] Usaquén Perilla, O.L., García Gómez, A., Alvárez Díaz, C. \& Revilla Cortezón, J.A., Methodology to assess sustainable management of water resources in coastal lagoons with agricultural uses: an application to the Albufera lagoon of Valencia (Eastern Spain). Ecological Indicators, 13, pp. 129-143, 2012. https://doi.org/10.1016/j.ecolind.2011.05.019

[44] FPIA, Informe de evaluación intermedia del Programa de Desarrollo Rural de la Comunitat Valenciana 2007-2013 (PDR-CV), Fundación para la promoción de la ingeniería agronómica, pp. 131-132, 2011, available in http://www.magrama.gob.es/es/desarrollo-rural/temas/programas-ue/periodo-de-programacion-2007-2013/seguimiento-yevaluacion/evaluaciones_2010.aspx (1 July 2014)

[45] Barbier, E.B., Valuing environmental functions: tropical Wetlands. Land Economics, 70(2), pp. 133-173, 1994.

https://doi.org/10.2307/3146319 
[46] MEA, Ecosystems and Human Well-Being. Synthesis, Island Press: Washington, DC: Millennium Ecosystem Assessment, 2005.

[47] Gomez-Limón, J.A. \& Arriaza, M., What does society demands from rural areas? Evidence from Southern Spain. New Medit. A Mediterranean Journal of Economics, Agriculture and Environment, 1, pp. 2-12, 2013.

[48] Champ, P.A., Boyle, K.J., Brown, T.C. (eds.), A Primer on Non-Market Valuation, Kluwer Academic Publishers: Boston, 2003.

[49] De Groot, R.S., Stuip, M.A.M., Finlayson, C.M. \& Davidson, N., Valuing wetlands: guidance for valuing the benefits derived from wetland ecosystem services, Ramsar Convention Secretariat, Gland, Switzerland \& Secretariat of the Convention on Biological Diversity, Montreal, Canada. Ramsar Technical Report No. 3/CBD Technical Series No. 27, 2006.

[50] Evans, D.J., Social discount rates for the European Union, Fifth Milan European Economy Workshops, Milan, 2006.

[51] http://data.worldbank.org/indicator/SP.DYN.CDRT.IN

[52] http://data.worldbank.org/indicator/NY.GDP.PCAP.PP.KD

[53] http://stats.oecd.org/index.aspx?DataSetCode=TABLE_I5\#

[54] http://stats.oecd.org/index.aspx?DataSetCode=TABLE_I4\#

[55] Ramsey, F., A mathematical theory of saving. Economic Journal, 38, pp. 543-559, 1928.

[56] Fishburn, P.C., The Foundations of Expected Utility, Reidel, Dordrecht, Holland, 1982. https://doi.org/10.1007/978-94-017-3329-8

[57] Keeney, R.L. \& Raiffa, H., Decisions with Multiple Objectives: Preferences and Value Trade-Offs, Wiley: New York, 1993. https://doi.org/10.1017/CBO9781139174084

[58] Hoehn, J. \& Randall, A., Too many proposals pass the benefit cost test. American Economic Review, 79(3), pp. 544-551, 1989.

[59] Adamowicz, W., Boxall, P., Williams, M. \& Louviere, J., Stated preference approaches for measuring passive use values: choice experiments and contingent valuation. American Journal of Agricultural Economics, 80(2), pp. 65-75, 1998. https://doi.org/10.2307/3180269

[60] Hanley, N., Wright, R. \& Adamowicz, V., Using choice experiments to value the environment: design issues, current experience and future prospects. Environmental and Resource Economics, 11(3-4), pp. 413-428, 1998.

https://doi.org/10.1023/A:1008287310583

[61] Colombo, S., Calatrava-Requena, J. \& Hanley, N., Analysing the social benefits of soil conservation measures using stated preference methods. Ecological Economics, 58(4), pp. 850-861, 2006. https://doi.org/10.1016/j.ecolecon.2005.09.010

[62] Mogas, J., Riera, P. \& Bennett, J., A comparison of contingent valuation and choice modelling with second-order interactions. Journal of Forest Economics, 12(1), pp. 5-30, 2006. https://doi.org/10.1016/j.jfe.2005.11.001

[63] SSPS Inc., SPSS 16.0 Command Syntax Reference, SPSS Chicago, 2007.

[64] Azqueta Oyarzun, D., Introducción a la economía ambiental, 2nd edn., McGraw-Hill/ Interamericana de España: Madrid, 2007. 
[65] Boyer, T. \& Polasky, S., Valuing urban wetlands: a review of non-market valuation studies. Wetlands, 24(4), pp. 744-55, 2004. https://doi.org/10.1672/0277-5212(2004)024[0744:VUWARO]2.0.CO;2

[66] Esteban, E. \& Dinar, A., Cooperative management of groundwater resources in the presence of environmental externalities. Environmental and Resource Economics, 54, pp. 443-469, 2013. https://doi.org/10.1007/s10640-012-9602-2

[67] Woodward, R.T. \& Wui, Y., The economic value of wetland services: a meta-analysis. Ecological Economics, 37, pp. 257-270, 2001. https://doi.org/10.1016/S0921-8009(00)00276-7

[68] Schuijt, K. \& Brander, L., Living Waters: Conserving the Source of Life. The Economic Value of the World's Wetlands, WWF, Gland (Switzerland), 2004.

[69] Brenner, J., Jiménez, J.A., Sardá, R. \& Garola, A., An assessment of the non-market value of the ecosystem services provided by the Catalan coastal zone, Spain. Ocean and Coastal Management, 53, pp. 27-38, 2010. https://doi.org/10.1016/j.ocecoaman.2009.10.008 


\section{APPENDIX}

Appendix 1: Eigenvalues and consistency ratios of the Total Economic Value in Albufera of Valencia from the survey in 2005.

Appendix 2: Eigenvalues and consistency ratios of the Total Economic Value in Albufera of Valencia from the survey in 2012.

Appendix 3: Eigenvalues and consistency ratios of the existence value in Albufera of Valencia.

Appendix 1: Eigenvalues and consistency ratios of the Total Economic Value in Albufera of Valencia from the survey in 2005.

\begin{tabular}{lllllll}
\hline Experts & DUV & IUV & OV & BV & EV & CR \\
\hline E1 & 0,0225 & 0,0651 & 0,0127 & 0,7470 & 0,1530 & $2.41 \%$ \\
E2 & 0,0275 & 0,0922 & 0,0103 & 0,7744 & 0,1144 & $4.13 \%$ \\
E3 & 0,0949 & 0,0543 & 0,0207 & 0,4150 & 0,4150 & $5.71 \%$ \\
E4 & 0,0058 & 0,0234 & 0,0808 & 0,4450 & 0,4450 & $3.12 \%$ \\
E5 & 0,1500 & 0,0500 & 0,0500 & 0,3750 & 0,3750 & $6.56 \%$ \\
E6 & 0,0189 & 0,1097 & 0,0114 & 0,4300 & 0,4300 & $7.45 \%$ \\
E7 & 0,0127 & 0,0740 & 0,0433 & 0,4400 & 0,4400 & $5.89 \%$ \\
E8 & 0,0238 & 0,0964 & 0,0098 & 0,7920 & 0,0880 & $2.45 \%$ \\
E9 & 0,0460 & 0,1461 & 0,0580 & 0,5025 & 0,2475 & $4.67 \%$ \\
E10 & 0,0527 & 0,1762 & 0,0210 & 0,6600 & 0,0975 & $4.23 \%$ \\
E11 & 0,0527 & 0,1762 & 0,0210 & 0,5625 & 0,1875 & $5.23 \%$ \\
E12 & 0,1396 & 0,0799 & 0,0305 & 0,1875 & 0,5625 & $8.72 \%$ \\
E13 & 0,0439 & 0,1083 & 0,0178 & 0,2200 & 0,6600 & $3.56 \%$ \\
E14 & 0,1593 & 0,0646 & 0,0262 & 0,1875 & 0,5625 & $6.89 \%$ \\
E15 & 0,0340 & 0,1020 & 0,0340 & 0,2075 & 0,6225 & $7.37 \%$ \\
E16 & 0,0294 & 0,0770 & 0,0336 & 0,7568 & 0,1118 & $3.56 \%$ \\
E17 & 0,4778 & 0,1937 & 0,0785 & 0,1875 & 0,0625 & $8.21 \%$ \\
E18 & 0,3450 & 0,2392 & 0,1658 & 0,1250 & 0,1250 & $2.65 \%$ \\
E19 & 0,4778 & 0,1937 & 0,0785 & 0,1250 & 0,1250 & $5.87 \%$ \\
E20 & 0,4927 & 0,2069 & 0,1304 & 0,1275 & 0,0425 & $4.46 \%$ \\
E21 & 0,3215 & 0,3215 & 0,1072 & 0,1675 & 0,0825 & $5.01 \%$ \\
E22 & 0,5636 & 0,1337 & 0,0528 & 0,1875 & 0,0625 & $8.93 \%$ \\
E23 & 0,0728 & 0,6418 & 0,1155 & 0,1275 & 0,0425 & $5.89 \%$ \\
E24 & 0,1068 & 0,1346 & 0,5087 & 0,0825 & 0,1675 & $3.97 \%$ \\
E25 & 0,0750 & 0,5669 & 0,2381 & 0,0650 & 0,0650 & $6.11 \%$ \\
\hline 10 & 0,050 &
\end{tabular}

DUV: direct use values; IUV: indirect use values; OV: option, quasi-option values; BV: bequest values; EV: existence values; CR: consistency ratio. 
Appendix 2: Eigenvalues and consistency ratios of the Total Economic Value in Albufera of Valencia from the survey in 2012.

\begin{tabular}{lllllll}
\hline Experts & DUV & IUV & OV & BV & EV & CR \\
\hline E1 & 0.1513 & 0.0999 & 0.0689 & 0.4968 & 0.1813 & $4.47 \%$ \\
E2 & 0.0393 & 0.4149 & 0.2338 & 0.1951 & 0.1124 & $5.34 \%$ \\
E3 & 0.0464 & 0.0967 & 0.1710 & 0.4185 & 0.2675 & $8.90 \%$ \\
E4 & 0.4562 & 0.0985 & 0.0503 & 0.2541 & 0.1409 & $9.57 \%$ \\
E5 & 0.0400 & 0.2549 & 0.0750 & 0.4466 & 0.1834 & $9.48 \%$ \\
E6* & 0.5929 & 0.0767 & 0.0422 & 0.1799 & 0.1084 & $10.75 \% *$ \\
E7 & 0.0838 & 0.1401 & 0.0594 & 0.3214 & 0.3954 & $9.29 \%$ \\
E8 & 0.2610 & 0.1401 & 0.0305 & 0.5156 & 0.0528 & $7.70 \%$ \\
E9 & 0.0374 & 0.1350 & 0.1350 & 0.3463 & 0.3463 & $2.14 \%$ \\
E10* & 0.4730 & 0.2655 & 0.0452 & 0.0743 & 0.1420 & $10.40 \% *$ \\
E11* & 0.0270 & 0.2767 & 0.0726 & 0.3301 & 0.2935 & $10.83 \% *$ \\
E12 & 0.4486 & 0.1514 & 0.0513 & 0.0881 & 0.2606 & $7.03 \%$ \\
E13 & 0.0464 & 0.0967 & 0.1710 & 0.4185 & 0.2675 & $8.90 \%$ \\
E14 & 0.1130 & 0.1766 & 0.0434 & 0.3777 & 0.2893 & $9.45 \%$ \\
E15* & 0.0291 & 0.1029 & 0.1742 & 0.5012 & 0.1926 & $10.73 \% *$ \\
E16 & 0.4486 & 0.1514 & 0.0513 & 0.0881 & 0.2606 & $7.03 \%$ \\
E17 & 0.0551 & 0.3091 & 0.0279 & 0.3091 & 0.2987 & $9.44 \%$ \\
E18* & 0.4756 & 0.0716 & 0.0296 & 0.2629 & 0.1604 & $32.88 \% *$ \\
\hline
\end{tabular}

DUV: direct use values; IUV: indirect use values; OV: option, quasi-option values; BV:

bequest values; EV: existence values; CR: consistency ratio. * indicates CR higher than $10 \%$.

Appendix 3: Eigenvalues and consistency ratios of the existence value in Albufera of Valencia.

\begin{tabular}{lllll}
\hline Experts & B & CH & AE & CR \\
\hline E1 & 0.6250 & 0.1365 & 0.2385 & $1.76 \%$ \\
E2 & 0.6483 & 0.1220 & 0.2297 & $0.36 \%$ \\
E3 & 0.6370 & 0.1047 & 0.2583 & $3.72 \%$ \\
E4 & 0.5396 & 0.1634 & 0.2970 & $0.89 \%$ \\
E5 & 0.7143 & 0.1429 & 0.1429 & $0 \%$ \\
E6 & 0.6370 & 0.1047 & 0.2583 & $3.72 \%$ \\
E7 & 0.6370 & 0.1047 & 0.2583 & $3.72 \%$ \\
E8 & 0.1047 & 0.6370 & 0.2583 & $3.72 \%$ \\
E9* & 0.6175 & 0.0856 & 0.2969 & $13.25 \% *$ \\
E10 & 0.8182 & 0.0909 & 0.0909 & $0 \%$ \\
E11* & 0.0727 & 0.2258 & 0.7016 & $23.03 \% *$ \\
E12* & 0.0513 & 0.3667 & 0.5820 & $5.19 \% *$ \\
E13 & 0.6370 & 0.1047 & 0.2583 & $3.72 \%$ \\
E14 & 0.1047 & 0.6370 & 0.2583 & $3.72 \%$ \\
E15 & 0.7778 & 0.1111 & 0.1111 & $0 \%$ \\
E16 & 0.1047 & 0.6370 & 0.2583 & $3.72 \%$ \\
E17 & 0.6000 & 0.2000 & 0.2000 & $0 \%$ \\
E18 & 0.7778 & 0.1111 & 0.1111 & $0 \%$ \\
\hline
\end{tabular}

